\title{
MAIN PERFORMANCE INDICATORS FOR A CONSTRUCTION COMPANY IN INDONESIA
}

\author{
Ima Fatima a , Dermawan Wibisono ${ }^{b}$ \\ ab Institut Teknologi Bandung, Bandung, Indonesia \\ Corresponding email: ima.fatima@sbm-itb.ac.id
}

\begin{abstract}
The era of free market and world economy globalization further encourages the opening of cooperation in various fields, as well as an opportunity for foreign investors to develop its business in Indonesia, not least in the sector of construction industry. This condition has certainly improved the climate of increasingly fierce competition in this sector.

To face this global competition, it is necessary to take some anticipatory steps to perform various improvements to the construction company to improve the quality of the company's performance. Efforts to improve the company's construction services can be done through a system of control over the factors that affect the company's performance that ultimately determine the success of company in achieving its goals.

This paper aims to identify and define main indicators that determine the performance of construction companies in Indonesia, as a first step in an effort to design a suitable Performance Management System (PMS) for construction industry. With specific reference to Knowledgebased Performance Management System (KBPMS), appropriate performance variables were chosen from various literatures. Questionnaires were addressed to the Executives of selected construction SOEs (state-owned enterprises). The Delphi method was conducted to analyze variables interrelation.

Findings of this case study research provide a set of main indicators that are useful as an initial step to design a PMS at corporate level for measuring performance of construction services companies in Indonesia.
\end{abstract}

Keywords: Construction Company, Corporate Level PMS, KBPMS, Performance Indicators.

\section{Introduction}

The era of free market, that has grown so vast and rapidly, further encourages the process of globalization of the world economy. It encourages the opening of cooperation in various fields, as well as an opportunity for foreign investors to develop its business in Indonesia. This condition will certainly improve the climate of increasingly fierce competition in the business world, not escape too in the sector of construction services business. Improving the ability of construction companies has become a necessity.

It is necessary to prepare strategic steps for creating a wide range of improvements to the company's construction services in an effort to improve the quality of the company's performance that has the ability to compete, nationally and internationally, today and in the future. Efforts to improve the company's construction services can be done through a system of control over the factors that affect the company's performance that ultimately determine the success of company in achieving its goals. Therefore, as a major step, it is necessary to identify 
and define critical indicators that determine the performance of the construction company in Indonesia.

Many studies were conducted to determine critical performance indicators. Most of them focused on the performance measurement on the project level. Research conducted on performance measurement at the company level is limited. In Indonesia, research on this specific area is still lacking. Therefore, a set of important indicators that can be used to measure and compare the performance of construction companies is lacking. To respond to this gap, this study was conducted as a part of preliminary research in an effort to design an appropriate Corporate Performance Management Systems for Indonesian construction companies. This study aims to identify a set of critical performance indicators that can be implemented by construction executives in measuring company level performance in Indonesia.

This paper discusses the factors that affect the company's performance quality of construction companies in Indonesia, through the identification and determination of important indicators that determine the success of the construction companies. The discussion is done through the study of literature and collection of secondary data from a large-class state-owned construction company in Indonesia.

The findings of this study is a set of important indicators that influence the success of the company. These key performance indicators will be used in the initiating of the development of a better performance measurement system that enable companies to be more competitive. However, the findings presented in this paper merely preliminary result of the initial stage of the research road map of desinging PMS for Indonesian construction companies.

\section{Proposed Framework}

The Construction industry is a dynamic industry, involves of complex internal and internal factors. As a result, performance management has become a significant way to facilitate business continuous improvement (Carillo, P.M., et al., 2005). Comprehensive measurement of a company's performance is vital for business transformation and enables businesses to be compared with each other on the basis of standardized information, allowing best practices to be identified and applied more widely (Mbugua et al., 1999).

The application of benchmarking in construction industry, including the identification of critical indicators, has emerged in many academic papers or journals. However, research on a performance evaluation and comparison at the company level is limited in the literature. Some institutes, such as the Construction Industry Institute (CII) in the USA, the Department of Environment, Transport, and the Regions (DETR) and the Department of Trade and Industry (DTI) in the UK, and the Corporation for Technical Development in Chile, have developed KPIs that are, to some degree, suitable for their own national features. Different market situations, policies and strategies, cultures, and competitive environments require different measures (Kaplan and Norton, 1993).

As other industrial sectors, construction companies formerly used financial measures to measure and evaluate their performance. According to Bassioni et al. 2004, dissatisfaction with financially based performance measurement lies in the fact that financial indicators are lagging indicators, in the sense that they tell the results of managerial actions already taken. Managers need nonfinancial information to be able to take better decisions.

Many efforts have been made by researchers to develop performance management frameworks in order to select and implement measures, that include financial and nonfinancial indicators, 
such as SMART (Cross and Lynch 1989), Performance Measurement Questionnaire (PMQ) (Dixon et al. 1990), Performance for World Class Manufacturing (PWCM) (Maskell 1991), Vital Signs (Hronec 1993), the Balanced Scorecard (BSC) (Kaplan and Norton 1996), the Malcolm Baldrige National Quality Award in the USA (MBNQA, 1987), the Performance Prism (Neely et al. 2002), and Knowledge Based Performance Management Systems (KBPMS) (Wibisono, 2006). Among others, the BSC, MBNQA, and Performance Prism were the most used.

The Balanced Scorecard (BSC) by Kaplan and Norton presents four perspectives from which executives can choose measures. The BSC complements financial indicators with operational measures on customer satisfaction, internal processes, and the organization innovation and improvement activities. Additional general perspectives have been identified, such as competition (Neely et al., 1995) and employee (Neely et al., 2000), as well as applicationspecific and supplier for construction (Kagioglou et al., 2001; Wang et al., 2010).

Malcolm Baldridge National Quality Award (MBNQA) is one of the most-utilized quality management models. It was recognized as descriptive holistic business models, rather than just quality model and mutated into framework for Business Excellence (Oackland and Marosszeky, 2006). The MBNQA promotes performance excellence and improvement in competitiveness through a framework of seven categories which are used to assess the organization leadership, strategic planning, customer focus, measurement, analysis and knowledge management, workforce focus, operation focus, and results (NIST, 2011).

Andy Neely and Chris Adams describe their 'Performance Prism' as 'a second generation performance management framework', which is needed to replace first generation models such as the balanced scorecard and the performance pyramid. The Performance Prism aims to manage the performance of an organization from five interrelated 'facets', i.e. (i) stakeholder satisfaction; (ii) stakeholder contribution; (iii) strategies; (iv) processes; and (v) capabilities. All previous frameworks pointed out the fact that performance measurement should be translated from strategy. However, Neely and Adams (2001) asserted that while measuring performance, stakeholder's needs and contributions have the first priority beyond the strategies, processes, and capabilities. 


\section{Asia Pacific Journal of Advanced Business and Social Studies \\ ISBN (eBook): 9780994365675 | ISSN : 2205-6033 \\ Year: 2017 , Volume: 3, Issue: 2}

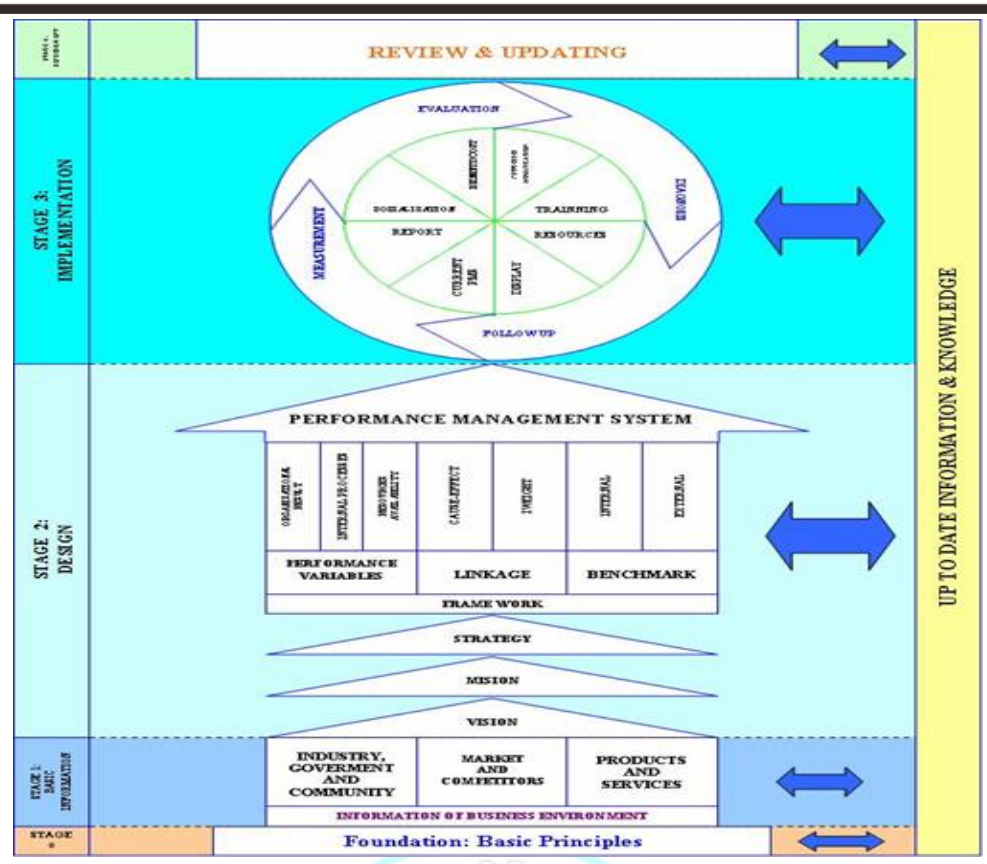

Figure 1: Performance Management System Design Methodology (Wibisono, 2012)

The Knowledge Based Performance Management Systems (KBPMS), proposed by Wibisono (2006), can be considered as a refinement of the concept of BSC, Performance Prism, and MBNQA, because it combines simplicity of design with attention BSC-Prism performances on the stakeholders, and clear direction of performance indicators from the MBNQA. The KBPMS can be visualized from strategic and operational structures. In the strategic part, there are two modules, namely Company Environment and Business Result Perspective. The Company Environment Module determines the particular environment in which the company operates. The Business Result Perspective Module analyses financial and non-financial performances. In the operational part, two modules, i.e., Internal Process Perspective and Resource Capability Perspective, are developed, and in each module there are sub-modules and performance variables. Figure 1 illustrated the design methodology of KBPMS.

\section{Methodology}

The research was conducted through a careful review of literature as to find supporting theories in identifying the problem faced by company in managing its performance. The internal and external analysis of current performance and business operation of the company was conducted using SWOT as well as TOWS analysis, followed by determining strategic plan for future potential improvement of the company.

The KBPMS approach was selected as the proposed framework for the PMS. Performance indicators were classified into three perspectives, i.e. business result, internal business process, and resource capabilities. A set of potential performance indicators then determined from rigorous study of literature, which are then validated through a case study in a state-owned construction company. 


\subsection{Case Study}

Data collection was conducted through a case study in a large-class state-owned construction company. Data were gathered primarily through a questionnaire survey as well as face-to-face interviews. A total of six pairwise comparison using two-tailed seven-point Likert scales questionnaires were addressed to the President Directors and Directors with direct semistructured interviews for modified gap and false alarm analysis. Both the questionnaire and interviews covered performance perspectives as proposed by KBPMS framework. Analytical Hierarchy Process (AHP), which was developed by Thomas L. Saaty in 1970s, is used to choose the suitable variables through the identification of the degree of importance.

A set of totally 162 potential indicators were selected and clustered into 11 subperspectives under 3 main perpectives, namely business result, internal business process, and resource capabilities. Thereafter, five most important indicators of each subperspective would be considered as the main performance indicators. The board of directors were chosen to be interviewed since they are the population of individuals who take responsible to achieve the company's performance target. Aferward, Delphi method was conducted to collect data for variables interrelation analysis of the main performance indicators with a designated team which consisted of five company's PMS experts in order to obtain a consensus about the ninepoint comparison scale (Saaty, 1980). Data were collected in two sessions with a pairwise comparison questionnaires and criteria weighting questionnaires specified for AHP analysis.

\subsection{Data Analysis}

Since the PMS that will be designed is for the corporate level, the unit of analysis is the company (organization). Current company performance was reviewed based on the annual reports during previous 5 years $(2011$ - 2015). First stage of designing a PMS begin with the determination of company statement covers the vision and mission, which expressed company's broad orientation and direction to be achieved. are expressed by vision and mission statements (Ferreira and Otley, 2009). Both company's vision and mission were analysed based on criteria proposed by Wibisono (2006). Afterward, company's basic information was analysed using SWOT method. The result of analysis then lead to strategies development using TOWS matrix. Analysis of gap and false alarm generated in proposed five most important performance indicators of each subperspective. The main performance indicators were then analysed using AHP methods. Following the AHP, consistency test based on consistency ratio (CR) have been conducted for all judgments from the company's PMS experts. Values of each CR were kept acceptable which is less than 0.1 as suggested.

\subsection{Validation and Benchmarking}

Validation and benchmarking have not been conducted yet in this study stage and were excluded in this paper. Validation of the proposed indicators will be done by asking other similar industry PMS experts' opinion about how acceptable the proposed performance indicators to the similar construction companies in general, following the KBPMS framework design methodology. Validation will be conducted by similar method to the initial case study, by addressing seven-point Likert scales questionnaire to general managers who responsible to manage PMS of four state-owned companies in construction industry. 
Benchmarking will be done internally and externally. Internally to identify previous company highest achievement of each indicator and externally to the four similar state-owned construction companies to identify best practice target.

\section{Analysis}

\subsection{Construction Industry Overview}

Construction industry plays an important and strategic role in national development. Contribution of the industry to the Gross Domestic Product reached 10\% in 2014, which puts it in position six of the nine major sector contributors to the national GDP (BPS, 2015). Moreover, according to BPS (2015), in the same year the construction sector is also able to absorb 7.3 million labor force (approximately 6.35\% of the national workforce).

Rapid development of infrastructure and construction in Indonesia lead to fiercely competitive business situations in construction industry. Moreover, as the largest construction market in the ASEAN, with a contribution of more than $67 \%$ of the market, Indonesia has become a very attactive market for international construction companies. Therefore, increasing competitiveness of national construction companies in order to face global competition becomes a necessity.

National construction industry involving 129,819 contracting companies with large qualification (2\%), intermediate/medium qualifications (13\%) and a small qualification (85\%) (BPS, 2015). This composition is dominated by a general contractors and a few specialized contractor companies (specialist contractors). Hypothetically, $85 \%$ of the value of the construction market dominated by non-small with $15 \%$ of the total number of 129,819 enterprises, while $15 \%$ of the value of the construction market contested by small contractors with $88 \%$ of the total number of business entities. This situation shows that although the number of entities of large contracting company (contractors) was small, its position is very significant in today's construction market leader.

The selected company for this study is one of the state-owned construction companies in the category of large qualification contractor. The number of national competitors in this category is significantly high. Todays, with the implementation of Asia free market and globalization, competitor of this company not only including national construction (SOEs and private) companies, but also foreign construction companies as well.

\subsection{Company Performance Review}

The Company implemented company's Score Card as their existing PMS. Their Score Card consists of four major parameters, i.e. finance, marketing, production, and human. Refers to the Key Performance Indicator (KPI) for the year 2015 in the target that set out in the Company's Work and Budget Plan (WBP) for 2015 financial year, in the aspects of revenue, profit from operation, and net income, it can be concluded that Company recorded an increased revenue amount of IDR 9.4 trillion or 8.5\% higher that was achieved in year 2014; IDR 8.7 trillion. This is due to an increase in total new contracts acquisition in year 2015. Meanwhile, on the profit from operation side, Company booked an increase of $17.4 \%$ to IDR 850.7 billion in the fiscal year 2015, from IDR 724.9 billion in 2014. In line with these, Company's net income also experienced an increase to IDR 463.7 billion, or 40.9\% higher compare to IDR 329.1 billion in 2014. 


\section{Asia Pacific Journal of Advanced Business and Social Studies \\ ISBN (eBook): 9780994365675 | ISSN : 2205-6033 \\ Year: 2017 , Volume: 3, Issue: 2}

On marketing aspect, the acquisition of new contracts in 2015 amounted to IDR 13.9 trillion with carry over projects from 2015 to 2016 amounted IDR 12.3 trillion. This performance has been achieved around 91.5\% of year 2015 WBP that amounted to IDR 15.2 trillion.

Company performance in production aspect represented an increased revenue amount to $8.5 \%$ in 2015 which was due to considerable number of contracts signed in 2014 that were realized into operating revenues in 2015.

In 2015, Human Resource Capital (HRC) Division of Company focused on strengthening organizational competency by recruiting fresh graduates, developing existing employees, and upholding the three pillars on the foundation of Company's core values (working smart, honest and responsible, modest). On account of that the Company aspired to produce excellent construction engineers in Indonesia. As of the end 2015, the Company had a total of 1,766 personnel, 1,232 of them are permanent employees while the rest 534 were contract employees. On the position basis, 34 were at General Manager level, 214 were Managers, while the staff comprised of 1,518 employees.

The successful accomplishments of the business is inseparable from the support and participation of all stakeholders including the community wherever Company operates. The Company expresses its moral responsibility toward the society and the environment through a commitment to continually develop both the CSR Program and the Partnership and Community Development Program.

\subsection{Company Vision, Mision, and Strategy}

Addressing the gradually increased competition within the construction industry, the Company redefined its vision, "To Become a Leading Construction Company in Southeast Asia". The company also launched "Beyond Construction" as a tagline, which reflects the Company's motivation to expand its business to other businesses related to their current core business. The Company initiated improvements in various aspects such as to strengthen the organization and to improve its internal capacity.

Company's mission is described in the following terms: Incorporated performance based on increasing corporate value; Apply learning process in achieving growth (increase corporate value); Implement simple, modest/applicable (down to earth) corporate culture; Proactively perform five lines of business through professional, governance practice to support corporate growth; Active participation in partnership and community development program and corporate social responsibility (CSR) along with corporate growth.

The strategies of the Company were analyzed using SWOT analysis, as well as TOWS matrix, as presented in Table 1.

In addition, being optimistic on the unlimited positive opportunities going forward, Company is ready to continue to work by: maximizing performance by instilling the company's incorporated core values, performing the learning process in order to achieve growth, implementing a simple and genuine corporate culture, being proactive in running its business lines professionally in accordance with good governance, which supports company's growth, and participating actively in the implementation of the Partnership and Community Development Program and Corporate Social Responsibility (CSR), which is in line with the company's progress. 
Table 1: SWOT and TOWS Matrix - Company Strategies

\begin{tabular}{|c|c|c|}
\hline $\begin{array}{c}\text { SWOT and TOWS } \\
\text { Analysis }\end{array}$ & $\begin{array}{l}\text { Strengths } \\
\text { - Company's maturity and long } \\
\text { experience, supported by a strong } \\
\text { balanced sheet, reliable resources, } \\
\text { solid management, and leading } \\
\text { brands as well } \\
\text { - Continuous improvements of the } \\
\text { organizational competency and } \\
\text { Company's internal capacity. } \\
\text { - Specialist and competent human } \\
\text { resources } \\
\text { - Investment in high profile projects } \\
\text { - Good safety performance }\end{array}$ & $\begin{array}{l}\text { Weaknesses } \\
\text { - Financial asset or } \\
\text { group of financial } \\
\text { assets is impaired } \\
\text { - Capability in tender } \\
\text { preparation for EPC } \\
\text { projects }\end{array}$ \\
\hline $\begin{array}{l}\text { Opportunities } \\
\text { - Potential construction } \\
\text { market, increase of } \\
\text { infrastructure demand } \\
\text { - High allocated national } \\
\text { budget for infrastructure } \\
\text { projects } \\
\text { - Presence of private } \\
\text { investment which grows } \\
\text { attractively } \\
\text { - Higher customer } \\
\text { requirements }\end{array}$ & $\begin{array}{l}\text { S-O Strategies } \\
\text { - Expand business by developing } \\
\text { other business cores such as EPC, } \\
\text { property, and precast manufacturing } \\
\text { - Improvement of supply chain } \\
\text { system } \\
\text { - Improve technology development, } \\
\text { included latest regulation and } \\
\text { environmental issues related to } \\
\text { construction } \\
\text { - Improvement of Human Resources } \\
\text { (HR) competences }\end{array}$ & $\begin{array}{l}\text { W-O Strategies } \\
\text { - Improvement of } \\
\text { product and service } \\
\text { quality } \\
\text { - Improve customer } \\
\text { - services } \\
\text { - Develop marketing } \\
\text { strategy to attract } \\
\text { more clients, } \\
\text { including more } \\
\text { intensively entering } \\
\text { international market }\end{array}$ \\
\hline $\begin{array}{l}\text { Threats } \\
\text { - Increase competition, } \\
\text { globalization, including the } \\
\text { implementation of the AFTA } \\
\text { and AEC/MEA (local and } \\
\text { international competitors) } \\
\text { - Failure in winning a tender } \\
\text { or a bid for a project, } \\
\text { especially an EPC project, } \\
\text { can lead to high cost }\end{array}$ & $\begin{array}{l}\text { S-T Strategies } \\
\text { - Develop joint venture and join } \\
\text { operation with other national and } \\
\text { internatinal construction companies } \\
\text { to capture more market share } \\
\text { - Develop strategic partnership with } \\
\text { other construction and construction } \\
\text { related companies to add capacity or } \\
\text { capability }\end{array}$ & $\begin{array}{l}\text { W-T Strategies } \\
\text { - Benchmark to other } \\
\text { constuction } \\
\text { company to improve } \\
\text { marketing } \\
\text { performance, } \\
\text { customer service and } \\
\text { challenging } \\
\text { employee career } \\
\text { path } \\
\end{array}$ \\
\hline
\end{tabular}

\section{Results}

\subsection{Performance Indicators}

A set of 162 proposed indicators were selected from several literatures, construction company's and author's proposition, while also taking into account the company's vision, mission and strategy. These indicators were selected based on three main perspectives and eleven subperspectives within the framework of KBPMS which are relevant to the construction industry, namely business result perpective which consists of investor, customer, supplier, government and society subperpectives; internal business process consists of innovation, operation process, and marketing subperspectives; and resource capability perpective with human resource, technology, and organization subperspectives. 
Asia Pacific Journal of Advanced Business and Social Studies

ISBN (eBook): 9780994365675 । ISSN : 2205-6033

Year: 2017 , Volume: 3, Issue: 2

Table 2: Weight Score of Main Performance Indicators

\begin{tabular}{|c|c|c|c|}
\hline Perspectives & $\begin{array}{l}\text { Sub- } \\
\text { perspectives }\end{array}$ & Indicators & $\begin{array}{l}\text { Priority } \\
\text { Vector } \\
\text { Average }\end{array}$ \\
\hline \multirow[t]{25}{*}{ Business Result } & \multirow[t]{5}{*}{ Investor } & Revenue and turnover growth & 0.08 \\
\hline & & Profit margin & 0.50 \\
\hline & & Earning after tax & 0.15 \\
\hline & & Cash flow performance & 0.03 \\
\hline & & Market capitalization & 0.24 \\
\hline & \multirow[t]{5}{*}{ Customer } & Quality of product/new service & 0.51 \\
\hline & & On time project completion & 0.24 \\
\hline & & Level of customer trust & 0.14 \\
\hline & & Customer satisfaction & 0.08 \\
\hline & & Performance quality & 0.03 \\
\hline & \multirow[t]{5}{*}{ Supplier } & $\begin{array}{l}\text { Stability of planning or scheduling } \\
\text { Stability of relationship between }\end{array}$ & 0.51 \\
\hline & & suppliers and company & 0.24 \\
\hline & & Number of suppliers & 0.03 \\
\hline & & On time payment to suppliers & 0.08 \\
\hline & & Supplier satisfaction & 0.14 \\
\hline & \multirow[t]{5}{*}{ Government } & Amount of Government support & 0.15 \\
\hline & & Vision alignment with Government & 0.25 \\
\hline & & $\begin{array}{l}\text { Alignment with the direction and goals of } \\
\text { Government programs } \\
\text { Relationship/work closely with }\end{array}$ & 0.48 \\
\hline & & Government & 0.04 \\
\hline & & Occupational health \& safety assessment & 0.08 \\
\hline & \multirow[t]{5}{*}{ Community } & Corporate Social Responsibility & 0.03 \\
\hline & & $\begin{array}{l}\text { Success of the Community Development } \\
\text { Program }\end{array}$ & 0.08 \\
\hline & & Image (positive-negative perception) & 0.14 \\
\hline & & Company approach to community & 0.25 \\
\hline & & $\begin{array}{l}\text { Public relations \& assessment results } \\
\text { achievement }\end{array}$ & 0.15 \\
\hline \multicolumn{4}{|l|}{ Internal Business } \\
\hline \multirow[t]{11}{*}{ Process } & \multirow[t]{6}{*}{ Innovation } & Creative innovation & 0.02 \\
\hline & & $\begin{array}{l}\text { Developing products/services effective \& } \\
\text { safely }\end{array}$ & 0.52 \\
\hline & & Anticipation of future customer needs & 0.07 \\
\hline & & Recent Innovations used for running a & \\
\hline & & business & 0.14 \\
\hline & & Number of patent & 0.24 \\
\hline & \multicolumn{3}{|l|}{ Operation } \\
\hline & \multirow[t]{4}{*}{ Process } & Acquisition of new contract & 0.24 \\
\hline & & Health operating cash flow & 0.02 \\
\hline & & Decrease in operating costs & 0.52 \\
\hline & & Appropriateness planning parameters & 0.07 \\
\hline
\end{tabular}




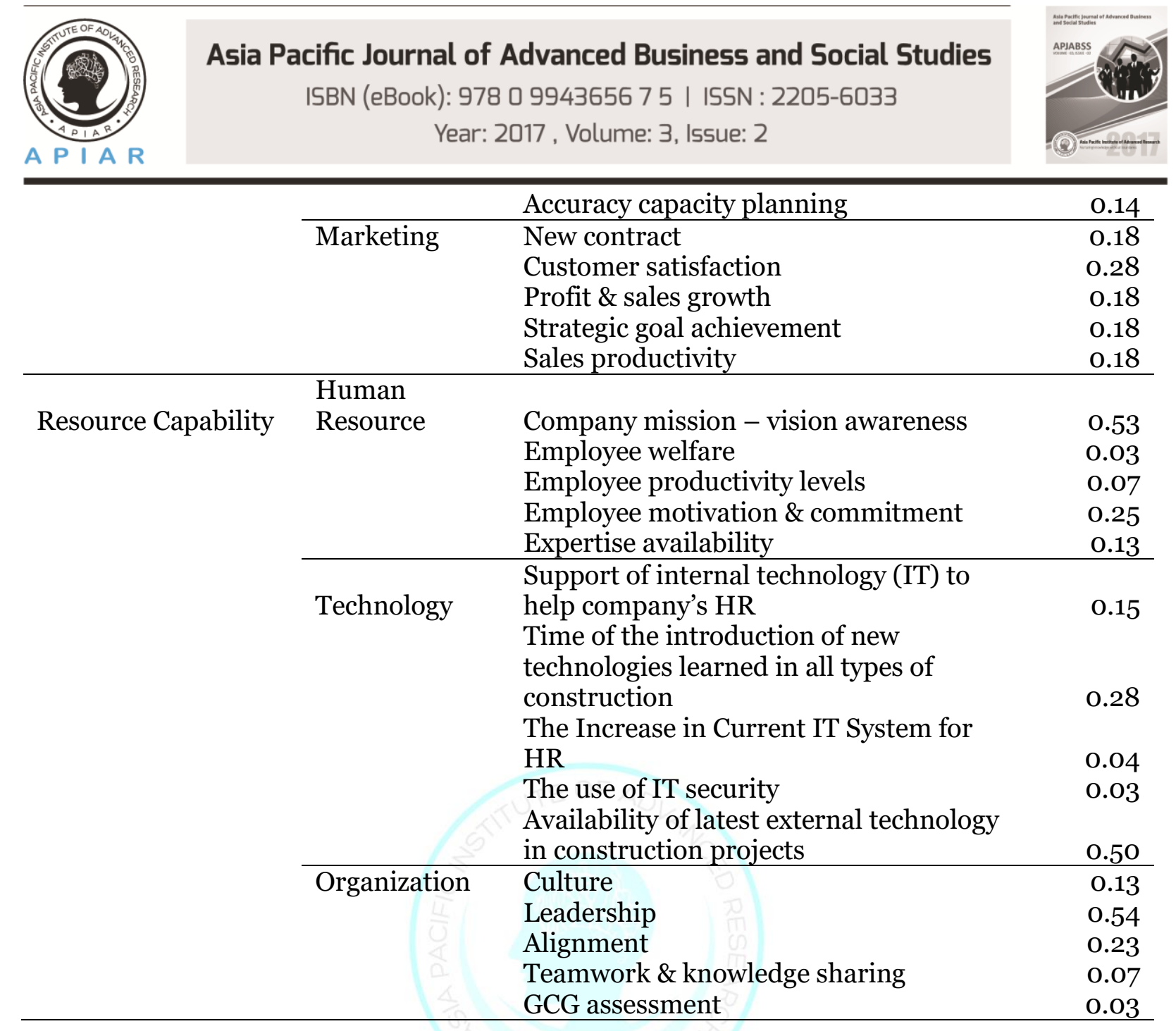

Through data collection and analysis, the relative importance of the main performance indicators was identified using AHP approach. Finally, 55 indicators were selected as the most significant indicators among 162 indicators listed in the questionnaire survey. Table 2 shows the most potential performance indicators which are proposed to be used in the development of a new PMS. The weight scores of the indicators after their hierarchical interrelations assessment are presented as well.

\subsection{Variables Interrelation Model}

As the result of indicators' level of importance assessment, there should be the 55 main performance indicators in a number of variables in different levels. The linkages are important to determine the causal effects among performance variables in the different levels and to define improvement priority that should be taken among performance variables in the same level. However, due to the lack of data and feedback from the Company at this stage, authors have not provided the list of weights. Figure 2 is presented to illustrate the model of variables hierarchical of interrelation. 


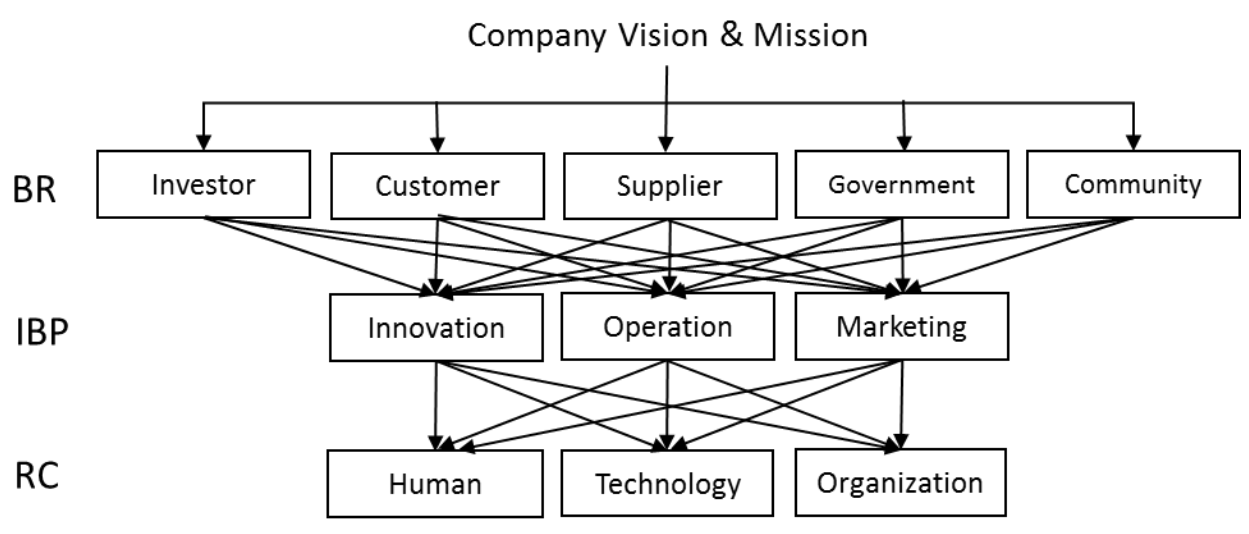

Figure 2: Variables Interrelation Scheme

To validate the proposed model, the process of validation using data collected from other companies in the construction industry will be conducted. And finally, benchmarking process will provide an overview of company highest achievements and identify best practice targets. However, validation and benchmarking process have not been included in this paper.

\section{Conclusion}

The findings of this study is a set of important indicators that influence performance of the company. Relying on a review of literatures, 162 performance indicators classified under three performance perspectives (and 11 sub perspectives). The analysis of the collected responses regarding the degree of importance of the 162 performance indicators is provided using 55 most significant indicators. The 55 indicators consistently perceived as being highly important can be used as a basis to build a model for evaluating the performance of construction companies and can also be considered as the first step for developing a competitive benchmarking approach. These performance indicators will be used in the initiating of the development of a better performance measurement system for construction companies in Indonesia at the corporate level which is enable national companies in this industry to be able to be more competitive and sustainable.

This study is the preliminary stage of the research road map in designing a PMS for construction companies in Indonesia. The study focused on large construction companies working in Indonesia where engineering companies in other disciplines were not included. It is recommended that more in-depth studies should be performed to better understand main performance indicators. Further studies may be conducted to standardize the methods for measuring the performance indicators, to determine relative weightings indicators and to develop benchmarking model based on the identified most important indicators to compare the performance of construction companies in Indonesia. 


\section{Asia Pacific Journal of Advanced Business and Social Studies}

ISBN (eBook): 9780994365675 । ISSN : 2205-6033

Year: 2017 , Volume: 3, Issue: 2

\section{References}

i. Bassioni, H.A., Price, A.D.F., Hassan, T.M. 2004. Performance Measurement in Construction, Journal of Management and Engineering, 20 (2), pp. 42-50.

ii. Carillo, P.M., Robinson, H.S., Anumba, C.J., Al-Ghassani, A.M. 2005. Review and Implementation of Performance Management Models in Construction Engineering, Construction Innovation Journal, 5 (4), pp. 203-217.

iii. Ferreira, A. and Otley, D. 2009. The Design and Use of Performance Management Systems: An Extended Framework for Analysis, Management Accounting Research, 20, pp. 263-282.

iv. Johnson, G., Scholes, K., Whittington, R. 2005. Exploring Corporate Strategy: Text and Cases, 7th ed., Prentice-Hall Financial Times, Pearson Education Limited.

v. Kaglioglou, M., Cooper, R., Aouad, G. 2001. Performance Management in Construction: A Conceptual Framework, Journal of Construction Management and Economy, 19, pp. 85-95, 2001.

vi. Kaplan, R. S., and Norton, D. P. 1996. The Balanced Scorecard: Translating Strategy into Action, President and Fellows of Harvard College, USA.

vii. $\quad$ Mbugua, L.M., Harris, P., Holt, G.D., Olomolaiye, P.O. 1999. A Framework for Determining Critical Success Factors Influencing Construction Business Performance, In: Hughes, W (Ed.), 15th Annual ARCOM Conference, 15-17 September 1999, Liverpool John Moores University, Association of Researchers in Construction Management, 1, pp. 255-264.

viii. National Institutes of Standards and Technology (NIST). 2011. Criteria for Performance Excellence Program.

ix. Neely, A. and Adams, C. 2001. The Performance Prism Perspective, Journal of Cost Management, 15 (1), pp. 7-15.

x. $\quad$ Neely, A., Gregory, M., Platts, K. 1995. Performance Measurement System Design: A Literature Review and Research Agenda, International Journal of Operation and Product Management, 15 (4), pp. 80-116.

xi. Oackland, J., Marosszeky, M. 2006. Total Quality in the Construction Supply Chain, $1^{\text {st }}$ Ed. Elsevier Ltd., Great Britain.

xii. $\quad$ Wang, O., El-Gafy, M., Zha, J. 2010. Bi-level Framework for Measuring Performance to Improve Productivity of Construction Enterprises, Construction Resource Congress, 2, pp. 970-979.

xiii. Wibisono, D. 2012. How to Create a World Class Company: Panduan Bagi Manajer dan Direktur, Gramedia Pustaka Utama, Jakarta.

xiv. Wibisono, D. 2011. Manajemen Kinerja Korporasi \& Organisasi: Panduan Penyusunan Indikator, Penerbit Erlangga, Jakarta.

xv. Wibisono, D., Khan, M.K. 2010. The Conceptual Framework of a Knowledge-based Performance Management System, Gadjah Mada International Journal of Business, 12 (3), pp. 393-414.

xvi. $\quad$ PT X (Persero) Tbk. 2015. Public Expose, Jakarta.

xvii. Badan Pusat Statistik. 2015. Distribusi Persentase Produk Domestik Bruto Triwulanan atas Dasar Harga Berlaku Menurut Lapangan Usaha, 2000-2014 (Persen). www.bps.go.id. accessed on January 25, 2016.

xviii. Badan Pusat Statistik. 2015. Tabel Penduduk 15 Tahun ke atas yang Bekerja Menurut Lapangan Pekerjaan Utama, 2000-2014. www.bps.go.id. accessed on January 25, 2016. 


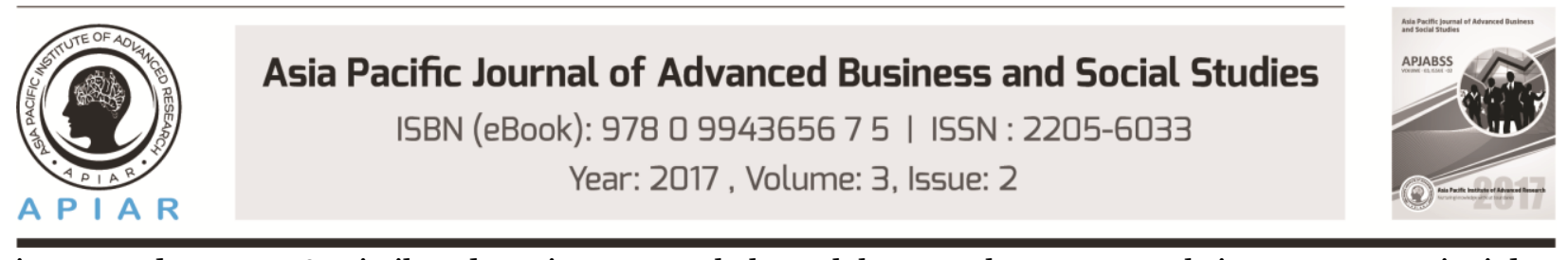

xix. Badan Pusat Statistik Indonesia. 2015. Tabel Jumlah Perusahaan Konstruksi Menurut Provinsi dan Jenis Golongan Perusahaan 2000-2014, www.bps.go.id, accessed on January 25, 2015. 